\title{
Comments
}

\section{BUYER'S REMEDIES IN THE SALE OF REAL PROPERTY IN CALIFORNIA}

The law governing rights and obligations of land vendors, land purchasers, and housing contractors developed when it was common for a person to purchase land and have a house constructed upon it for his own use. If he moved he sold it to an individual who was frequently no more expert in home construction than himself, and no better equipped to imspect and discover latent defects. ${ }^{1}$ The vendor liad a duty to inform the purchaser of any known defects, but was not responsible for defects of which he had no knowledge. ${ }^{2}$ Any loss due to such hidden and unknown defects fell on the purchaser-caveat emptor.

The home construction industry has, however, seen great changes. More and more houses are mass produced in tract developments and sold after completion. ${ }^{3}$ With the increase in mass produced housing, vendor and purchaser are no longer equally able to discover construction defects, because the vendor is usually either the home builder or is closely connected with him, and can be expected to know far more than the purchaser about how the house is built. The builder-vendor has an opportunity to inspect the houses while they are being constructed, whereas the purcliaser ordinarily does not see the louse until it has been completed. Because lie cannot inspect, the buyer must rely almost exclusively on the skill of the builder-vendor to produce a house fit to live in. The buyer relies on the vendor as builder. Impliedly, the builder-vendor holds himself out as an expert in the field.

Another phenomenon of the housing boom has been the activity of lenders in financing large developments. The amount loaned is calculated on the basis of the estimated value of the houses when completed. In order to protect its investment a lender will usually make provision for its own inspection of the houses. The inspection is used to insure that the plans on which the loan was based are being complied with so the security for the loan will be sufficient. As an important by-product of this activity, the buyer of a defective home may have an additional defendant when suing for damages.

The purposes of this Comment are four: to explore the remedies

I See Note, 18 MD. L. REv. 332, 335 (1958).

2 Prosser, TORTs § 102, at 713 (3d ed. 1964) [hereinafter cited as Prosser].

3 "Since the end of World War $I I$, over 2 million single family dwellings have been built in California, 1.4 million of which have been in subdivisions." Volpert, Creation and Maintenance of Open Spaces in Subdivisions: Another Approach, 12 U.C.L.A.L. REv. 830,831 n.4 (1965). 
presently available to the purchaser of a defective home; to look for indications that the California courts recognize the disparity in knowledge and bargaining position between the builder-vendor and the purchaser; to see if the changes in the construction industry justify an extension of warranty liability to the sale of real property; and to determine whether a lender should be liable to the buyer for construction defects.

\section{I}

FRAUD

The courts have never allowed the doctrine of caveat emptor to bar an action against a seller when fraud is shown. ${ }^{4}$ To prove actionable fraud in California the buyer must show that a false representation was made to induce him to act and that he in fact relied on the false representation to his detriment..$^{5}$ Misrepresentation includes the nondisclosure of a material fact, ${ }^{6}$ even though the parties do not stand in a confidential or fiduciary relationship. What constitutes a material fact depends upon the circumstances of the individual case. Facts deemed to be material have included construction of a house on fill, ${ }^{7}$ a roof that leaked during heavy rains, ${ }^{8}$ knowledge that the purchaser's intended use was to be declared illegal, ${ }^{\circ}$ and knowledge that the buildings violated the building codes. $^{10}$ There is also language suggesting that a vendor may be held liable for negligent nondisclosure: ${ }^{11}$ failure to disclose a fact not known by him which he would have discovered in the exercise of reasonable care.

4 Bearman, Caveat Emptor in Sales of Realty-Recent Assaults Upon the Rule, 14 VAND. L. REv. 541, 561 (1961) [hereinafter cited as Bearman].

5 Cat. Civ. Code $\& 1709$. See generally Prosser $\$ 100$.

6 CaL. Crv. Code $\S \S 1572(3), 1710(3)$; e.g., Lingsch v. Savage, 213 Cal. App. $2 d$ 729, 29 Cal. Rptr. 201 (1963) ; Buist v. C. Dudley DeVelbis Corp., 182 Cal. App. 2d 325, 6 Cal. Rptr. 259 (1960) ; Curran v. Heslop, 115 Cal. App. 2d 476, 252 P.2d 378 (1953); Barder v. McClung, 93 Cal. App. 2d 692, 209 P.2d 808 (1949); Clauser v. Taylor, 44 Cal. App. 2d 453, 112 P.2d 661 (1941); see Note, 29 So. CaL. L. Rev. 378 (1956).

7 Rothstein v. Janss Investment Corp., 45 Cal. App. 2d 64, 113 P.2d 465 (1941); Clauser v. Taylor, 44 Cal. App. 2d 453, 112 P.2d 661 (1941).

8 Herzog v. Capital Co., 27 Cal. 2d 349, 164 P.2d 8 (1945).

9 Dyke v. Zaizer, 80 Cal. App. 2d 639, 182 P.2d 344 (1947). Here defendant leased a store room that was being used as an amusement center to the plaintiff although the defendant knew that the operation of certain equipment used in the center was going to be declared illegal by city officials. The inability to operate this equipment resulted in an operating deficit for the plaintiff.

10 Lingsch v. Savage, 213 Cal. App. 2d 729, 29 Cal. Rptr. 201 (1963); Curran v. Heslop, 115 Cal. App. 2d 476, 252 P.2d 378 (1953); Tatham v. Pattison, 112 Cal. App. 2d 18, 245 P.2d 668 (1952); Milnoe v. Dixon, 101 Cal. App. 2d 257, 225 P.2d 273 (1950).

11 See Doran v. Milland Dev. Co., 159 Cal. App. 2d 322, 324, 323 P.2d 792, 794 (1958). In Doran the court stated that once the defendant said anything about the subject he was liable for failure to tell all, including facts that he should have known in the exercise of reasonable care. However, this statement was dicta because express misrepresentation was found. 
In addition to liability for an intentionally false representation, ${ }^{12}$ a vendor in California is lield for false statements he believes to be true but which are made without reasonable grounds for such belief. ${ }^{13}$ Thus, a builder-vendor was held liable for his statement that the foundation was "properly built," when in fact it violated the city building codes. ${ }^{14}$ The court found this statement a misrepresentation though the defendant believed it to be true: The city building inspector had failed to call the violation to his attention.

The defrauded purchaser can seek either rescission ${ }^{16}$ or damages, ${ }^{10}$ depending upon the circumstances of the case. ${ }^{17}$ If the fraud is unintentional or the damage relatively slight, courts are more hikely to grant rescission. ${ }^{18}$ If the seller has purposely defrauded the buyer damages will be granted, courts feeling damages to be the heavier burden. ${ }^{10}$ However, since selling a house can require a mucli larger investment of time and money than does the sale of other real property, rescission may be a heavier charge than damages because the builder-vendor must not only correct the defect or reduce the price, but also must take the loss on the original selling expenses and expend additional time and money in resale. ${ }^{20}$ Hence, damages may be the lesser burden and therefore the better remedy for a neghigent misrepresentation in the sale of a house. ${ }^{21}$

12 E.g., McCue v. Bruce Enterprises, Inc., 228 Cal. App. 2d 21, 39 Cal. Rptr. 125 (1964) ; Perkins v. Ketchum, 211 Cal. App. 2d 245, 27 Cal. Rptr. 278 (1962); Doran v. Milland Dev. Co., 159 Cal. App. 2d 322, 323 P.2d 792 (1958); Ashburn v. Miller, 161 Cal. App. 2d 71, 326 P.2d 229 (1956) ; Burkett v. J. A. Thompson \& Son, 150 Cal. App. 2d 523, 310 P.2d 56 (1957); Tatham v. Pattison, 112 Cal. App. 2d 18, 245 P.2d 668 (1952); Blackman v. Howes, 82 Cal. App. 2d 275, 185 P.2d 1019 (1947).

13 CAL. CIv. Code $\$ \S 1572(2), 1710(2)$; see, e.g., Balfour, Guthrie \& Co. v. Hansen, 227 Cal. App. 2d 173, 38 Cal. Rptr. 525 (1964); Doran v. Milland Dev. Co., 159 Cal. App. 2d 322, 323 P.2d 792 (1958).

14 Doran v. Milland Dev. Co., 159 Cal. App. 2d 322, 323 P.2d 792 (1958); see note 11 supra.

15 See, e.g., Tatham v. Pattison, 112 Cal. App. 2d 18, 245 P.2d 668 (1952); Rothstein v. Janss Investment Corp., 45 Cal. App. 2d 64, 113 P.2d 465 (1941); Clauser v. Taylor, 44 Cal. App. 2d 453, 112 P.2d 661 (1941).

16 See, e.g., Balfour, Guthrie \& Co. v. Hansen, 227 Cal. App. 2d 173, 38 Cal. Rptr. 525 (1964); Perkins v. Ketchum, 211 Cal. App. 2d 245, 27 Cal. Rptr. 278 (1962); Ashburn v. Miller, 161 Cal. App. 2d 71, 326 P.2d 229 (1958); Rothstein v. Janss Investment Corp., 45 Cal. App. 2d 64, 113 P.2d 465 (1941).

17 See Note, 4 W. REs. L. REv. 357, 367-68 (1953).

18 Bearman 563; Prosser § 105, at 749-50. See also Prosser $\$ \S 100-02$.

10 Ibid.

20 Bearman 564.

$21 \mathrm{Id}$. at 563-64. However, there is statutory authority in Califorma for seeking rescission for negligent misrepresentation. CAI. Crv. CODE $\$ 1572(2)$. There is a conflict of authority as to the measure of damages for fraud in the inducement to contract. The minority rule is that a person should receive his "out of pocket" loss; that is, the difference between the value he has parted with and the value he has received. The rule followed in the majority of jurisdictions is the "benefit of the bargain" rule which allows recovery for 
Nor is the builder-vendor's liability at an end when the original purchaser sells the house: In Burkett v. J. A. Thompson $\mathcal{E} S^{2}{ }^{22}$ a district court of appeal granted relief to the original purcliaser's vendee. It lias been argued that without some period of limitations these suits are practically impossible to defend, that extensive records must be kept over a long period of time, and that insurance would be difficult if not impossible to obtain because of the long period of potential liability..$^{23}$ Moreover, sucli long-extending liability could discourage some people from investing in housing projects for fear of liability in later years, thus raising the cost of financing construction and consequently the cost to the purcliaser. Furthermore, unlike the situation where the misrepresentation is intentional, extending liabihty beyond the first purchaser would not deter one whose actionable conduct is based on negligence. ${ }^{24}$

the difference between the actual value of the property received and its value if it had been as represented. PROSSER § 105. This is the same measure of damages used under both the Uniform Sales Act and the Uniform Commercial Code for breach of warranty. UNIFORAS Sales ACT $\S 69(7)$; UNIForas Comarercial Code $\S 2-714(2)$. The minority rule is more consistent with the purpose of tort liability: to compensate the plaintiff for the loss sustained. Prosser $₹ 105$, at 751. However, in support of the majority rule, it is pointed out that it is also the measure for breach of warranty. The plaintiff should not recieve less for an intentional wrong than he would for the unintentional warranty breach, which would be the anomalous result under the "out of pocket" rule. Since the adoption of Civil Code \$ 3343 in 1935, California has been committed to the "out of pocket" rule. See, e.g., Gagne v. Bertran, 43 Cal. 2d 481, 275 P.2d 15 (1954); Perkins v. Ketchum, 211 Cal. App. 2d 245, 27 Cal. Rptr. 278 (1962); Milnoe v. Dixon, 101 Cal. App. 2d 25', 225 P.2d 273 (1950); Rothstein v. Janss Investment Corp., 45 Cal. App. 2d 64, 113 P.2d 465 (1941). Nevertheless, the courts' application of the rule has not been entirely consistent. In Ashburn v. Miller, 161 Cal. App. 2d 71, 326 P.2d 229 (1958), for example, while claiming to apply the rule set out in the code, the court actually used the "henefit of the bargain" rule, awarding the plaintiff the difference between the value of the lot as filled and what it would have been worth had it not been filled.

22150 Cal. App. 2d 523, 310 P.2d 56 (1957).

23 Assearbly Intertu CoMmittee on Judictary, Final Report 18-19 in Assembly INTERAM COMAMTTEE REPORTS (1963-65), VoL. 23, No. 5 (1965). The committee rejected these arguments and recommended against the passage of Assembly Bill 648 (1963) which would have provided that no action could be filed against a contractor or certain other parties involved in the construction process when six years had elapsed since the services had been performed, whether or not the defect had heen discovered. The committee concluded that the proposal would bar justifiable claims, that the advocates of the bill had adequate existing protection against stale or false claims, and that the burden on the contractor and the other parties in protecting themselves against potential liability did not justify a bar to legal action. Moreover, the committee found that adequate insurance could be obtained although the cost would be somewhat higher than if the liability were more confined. The committee was, however, concerned only with defective or unsafe improvements on real property and its findings and conclusions need not foreclose all hope for an effective statute of limitations for causes of action based on misrepresentations negligently made.

24 Indeed, it has been suggested that in many cases of negligence no fault is involved; the party held liable is as innocent as the victim. Ehrenzweig, A Psychoanalysis of Negligence, 47 Nw. U.I. REv. 855, 856-57 (1953). 
The current attitude of the California judiciary toward misrepresentation by a builder-vendor in the sale of housing can be illustrated by examining two cases. In Burkett v. J, A. Thompson $\mathcal{E}$ Son, ${ }^{25}$ the buildervendor was lield liable for damage caused to the plaintiff's louse by subsidence of fill. Defendant's agent had stated that the house was constructed on "original ground" when he knew it was not. The lot in question had been approved by the Department of Building and Safety of the City of Los Angeles and by the Federal Housing Authority as fit for the construction of a one story residential building, and this approval had been communicated to the contractor who constructed the home. The contractor found no evidence of improperly compacted fill while digging the foundation nor did the city inspector or the loan inspector who approved the excavation. There was testimony that the "hilly character of the immediate vicinity would have suggested to any person who inspected the lot that it had been filled and graded."26 Nevertheless, the district court of appeal ruled that the vendor had actionably deceived the purchaser. Similarly, the builder-vendor in McCue v. Bruce Enterprises, Inc., ${ }^{27}$ was held liable for misrepresentation resulting from a statement by his salesman that the homes were "on city utilities." The fraud consisted of failing to inform the purcliasers that a septic tank was used rather than city sewer facilities. The houses had been constructed according to plans that the defendant had filed with the Federal Housing Authority. The percolation test the defendant had made to determine the feasibility of a septic tank system met the minimum standards of the county health ordinances. Due to some defect in the soil, however, the system did not function properly, making it necessary for the plaimtiffs to correct the defect at considerable expense. Even though the plans and specifications were available for inspection at the FHA offices, the court ruled that the type of sewage system used "was not within reach of the diligent attention . . . of the plaintiffs"28 and therefore the availability of the plans was no defense to misrepresentation.

In view of Burkett, where the surrounding vicinity suggested the existence of a fill, and $M c C u e$, where the plans were available for inspection, it appears that nothing short of actual knowledge on the part of the purchaser will relieve the vendor of his duty to disclose. Since the only

25150 Cal. App. 2d 523, 310 P.2d 56 (1957).

26 Id. at 525,310 P.2d at 57.

27228 Cal. App. 2d 21, 39 Cal. Rptr. 125 (1964).

${ }^{28}$ Id. at 28, 39 Cal. Rptr. at 129. The misrepresentation here was based on the defendant's duty to disclose all he knew once he had undertaken to speak on the subject. CAI. CIv. Code. § 1710(3). 
person who can testify as to actual knowledge is in most cases the purchaser, this rule, in effect, forces the vendor to disclose everything. ${ }^{29}$

An essential element of a cause of action based on misrepresentation is that the misrepresentation play a substantial part in leading the plaintiff to adopt his particular course of action..$^{30}$ Furthermore, there must be a causal connection between the misrepresentation and the damage incurred..$^{31}$ It is questionable whether the defendant's statements in either Burkett or $M c C u e$ played a substantial part in the plaintiff's choice of action. The evidence in Burkett that the surrounding vicinity gave notice of the existence of fill implies that the purchaser did not consider this an important factor in determining whether or not to buy. If the existence of fill would have deterred him, he would have been on the alert for any hints of such a condition. Similarly, if the existence of a septic tank in $M c C u e$ would have prevented the purchasers from buying, whether or not it functioned properly, they might have attempted to examine the plans. Admittedly the vendor's representations may have convinced them that there was no need to investigate. However, the buyer's testimony after the damage as to his feelings about septic tanks and the effect of the seller's representations is at least open to question. Had the purchasers been shown that the septic tank would function properly, they probably would not have refused to buy. Moreover, the vendor had done what the law required to insure that the septic tank would perform as it should. There was, therefore, no causal connection between the representation and the damage. Likewise, in Burkett, it was not the existence of the fill that caused the damage but poor compaction. Had the presence of fill been known to the plaintiff he would presumably have done no more than inspect its fitness, and the evidence of this would probably have been as sufficient to satisfy him as it had been to the city and loan inspectors. The defendant had done all he could reasonably be expected to do to insure that the fill had been adequately compacted; he could not be held for negligence. Since in both cases there was a specious causal connection between the representation and the damage, as well as a tenuous showing that the representation played a substantial part in determining the plaintiffs' course of conduct, both factors being essential to the cause of action, judgment for the plaintiffs obviously required resolving every doubt in their favor.

29 A provision in the contract to the effect that the purchaser disclaims any reliance as to representations not contained therein does not relieve a vendor from liability for fraud because it is said that the fraud vitiates the contract. See, e.g., Rotlistein v. Janss Investment Corp., 45 Cal. App. 2d 64, 113 P.2d 465 (1941); CaI. Crv. Code § 1668.

30 Prosser $§ 103$, at 729.

31 Id. $\S 105$, at 748 . 


\section{II}

\section{NEGLIGENCE}

Another remedy afforded the purchaser of a defective home is an action for damages agamst the builder for negligent workmanship. If the builder contracted to build the house directly for the purchaser, the purchaser may recover for negligent failure to perform the terms of the contract. $^{32}$ Thus, the builder in Fireman's Insurance Co. v. Indermill, ${ }^{33}$ was held liable for his subcontractor's negligence in failing to comply with the city ordinance whicl required that caissons extend twelve inclies into the natural soil. The caisson loles liad been inspected for depth and approved by the county building inspector before the concrete was poured. However, the court ruled that this inspection did not relieve the defendant of his duty of care in liaving the caisson holes drilled to a sufficient depth.

If, as in many large developments presently being built, the house is constructed by the defendant in his capacity as a builder for limself as a seller or for a vendor who is closely connected with him, there is no contract between buyer and builder on which a complaint for negligence can be based. Until recently, once a house had been completed and accepted by the original owner the builder was not liable for injuries caused by his negligence to anyone not a party to the contract. ${ }^{34}$ The California courts no longer adhere to this rule and have said that the determination of whether liability exists without privity is a matter of policy to be determined by balancing several factors: ${ }^{35}$ "the extent to whicl the transaction was intended to affect the plaintiff, the foreseeability of harm to him, ... the closeness of connection between the defendant's conduct and the injury suffered, and the policy of preventing future harm." ${ }^{\prime 36}$ This analysis was first employed to loold a subcontractor liable to one not in privity for negligent construction of a swimming $\mathrm{pool}_{,}^{37}$ and then extended in Sabella $v$. Wisler ${ }^{38}$ to include liability for

32 E.g., Kavalaris v. Anthony Bros. Inc., 217 Cal. App. 2d 737, 32 Cal. Rptr. 205 (1963); Fireman's Ins. Co. v. Indermill, 182 Cal. App. 2d 339, 6 Cal. Rptr. 469 (1960).

33182 Cal. App. 2d 339, 6 Cal. Rptr. 469 (1960).

34 Boswell v. Laird, 8 Cal. 469, 498 (1857) (dictum), followed in Kolburn v. P. J. Walker Co., 38 Cal. App. 2d 545, 101 P.2d 747 (1940).

85 Sabella v. Wisler, 59 Cal. 2d 21, 377 P.2d 889, 27 Cal. Rptr. 689 (1963); Stewart v. Cox, 55 Cal. 2d 857, 362 P.2d 345, 13 Cal. Rptr. 521 (1961); Biakanja v. Irving, 49 Cal. 2d 647, 320 P.2d 16 (1958).

36 Stewart v. Cox, supra note 35, at 863,362 P.2d at 348, 13 Cal. Rptr. at 524.

37 Stewart v. Cox, 55 Cal. 2d 857, 362 P.2d 345, 13 Cal. Rptr. 521 (1961).

3859 Cal. 2d 21, 377 P.2d 889, 27 Cal. Rptr. 689 (1963). See also 4 Santa Clara Lawyer 141 (1963). Sabella and Stewart, supra note 37, relied on Biakanja v. Irving, 49 Cal. 2d 647, 320 P.2d 16 (1958), a case not involving real property. In Biakanja a notary public 
negligent construction of a house. In Sabella, the builder negligently failed to determine whether the ground would support a house and was lield liable for the damage which resulted when the house settled on the improperly compacted fill. The court reasoned that the plaintiffs were members of the general class of prospective home buyers for whoin the house was constructed; a duty of care was owed the plaintiffs by virtue of the relationship; the transaction was clearly intended to affect the class of which plaintiff was a member; damage was certainly foreseeable if the house was constructed on inadequately compacted fill; there was a close connection between the negligent workmanship and the injury suffered; and finally, prevention of future harm due to construction of homes on unstable fill would not be furthered by exempting the defendant from hability. It may be concluded that the court laid down as rules of law, for which no proof need be adduced, that when a home is constructed by a builder-vendor for sale to the general public the transaction is intended to affect the purchaser, property damage to him is foreseeable if the work is negligently done, and holding the binldervendor liable for damages for neghigence will prevent future harin by encouraging greater care on the part of the builder-vendor. A plaintiff need show only a close causal connection between the defendant's conduct and the injury, and actual damage - both factual questions. Liability without privity in the builder-vendor situation is settled when the necessary factual showing can be made.

One writer has argued that hability without privity should not be extended into the law of realty sales without more careful consideration. ${ }^{39}$ He points out that a home is more complex than an ordinary chattel and it is more bikely that something will go wrong, and suggests instead, therefore, that the purchaser be held to a more rigid inspection. This recommendation fails, however, to recognize that the ordinary home buyer lacks expertise in the business of housebuilding and probably cannot afford to hire someone who is able to make an adequate inspection. The builder, who has the expertise, is in a nuch better position to make the inspection as the work progresses. To require the buyer to make a rigid inspection would probably force him to hire his own progress inspector, at great cost, largely defeating the purpose of large low-cost developments. ${ }^{40}$ Moreover, because many tract homes are not purchased until after completion, progress supervision would often be impossible.

was held liable to one of the legatees of an invalid will for failure to have the will executed properly.

39 Bearman 569.

40 Note, 18 MD. L. REv. 332, 335 (1958). 
Another argument against extending the doctrine of liability without privity into the realty field is based upon the effect of the weather in creating or aggravating defects in a home. ${ }^{41}$ It will be difficult, it is said, for the builder-vendor to show a distinction between those defects caused by his negligence and those caused by the elements. The purchaser is, however, faced with the same problem; and since he carries the burden of proof, he must show that the defect was the result of negligence before the builder is called upon to prove anything.

Nevertheless, there are drawbacks to extending liability without requiring privity. For example, the lack of an effective statute of limitations is a major problem. ${ }^{42}$ Although the statute of limitations for injury to real property is three years, ${ }^{43}$ in a negligence action the statute does not start to run until the plaintiff discovers or should have discovered the neghigently-caused defect or damage; $;^{44}$ as long as the purchaser can estabhsh a continuing connection between the defect and the damage, the builder will be kable. ${ }^{45}$ The policy behind this far-reaching liability is the desire to reheve the plaintiff of the hardship of having to bear the entire loss. ${ }^{46}$ This rule presents a very serious problem to the buildervendor, as illustrated by Hale v. Depaoli. ${ }^{47}$ There the builder-vendor was held hable for a defect in a house built in 1925 when the injury occurred in 1943. Eighteen years is a long time to hold a builder for defects when there is an increasing probability that they are due not to lack of care but rather to ordinary wear and tear, or any number of causes not within the power of the defendant to prevent or control. Moreover, after this length of time it becomes increasingly difficult for him to gather evidence on his behalf ${ }^{48}$ unless he has retained extensive records at great expense. The practical result under the present rule is that the builder-vendor is never free from possible liability.

Some reasonable time himit on the negligence liability of a buildervendor would appear to be necessary. A balance must be struck between the hardship on the plaintiff in forcing him to bear the entire loss and the defendant's difficulty in gathering evidence after a substantial period of

41 Bearman 569.

42 See discussion of Assembly Bill 648 (1963) at note 23 supra and accompanying text. 43 Cal. Code Crv. Proc. $\$ 338(2)$; Automobile Ins. Co. v. Union Oil Co., 85 Cal. App. 2d 302, 307, 193 P.2d 48, 51 (1948).

44 Prosser $\S 30$, at 147-48. See also Coots v. Southern Pac. Co., 49 Cal. 2d 805, 322 P.2d 160 (1958).

45 Bearman 569-70. Since this is a jury question, it is likely that causal connections of dubious lengths may be found.

46 Prosser $\S 30$, at 147.

4733 Cal. 2d 228, 201 P.2d 1 (1948). This case involved a personal injury which may explain why the court allowed a cause of action after such a long tine.

48 PROSSER $\$ 30$, at 147 . The burden of proof, however, remains on the nuoving party. See note 41 supre and accompanying text. 
time. It might be possible to split the loss equally between the plaintiff and the defendant after a prescribed period of time has elapsed, thus eliminating the necessity of forcing the plaintiff to bear the entire loss and somewhat alleviating the defendant's burdensome evidentiary problem.

The viewpoint of the Cahfornia courts in the area of negligence is reflected first, by what they find to be negligent conduct, and second, to whom they find a duty of care is owed. In Fireman's Insurance Co. v. Indermill, 99 for example, the district court of appeal found the builder negligent in failing to make sure caissons extended far enough into the natural soil; the city building inspector had approved them as satisfactory. Similarly, the builder-vendor in Doran v. Milland Dev. Co. ${ }^{50}$ was found to have been neghigent in representing that the foundation was "properly built" when it violated the building code, though the city building mspector had not called the defect to his attention when giving his approval.

The position of the California judiciary becomes even clearer when the expanded range of possible defendants in a negligence action is considered. The California courts liave continually broadened the hability of the builder until he now owes a duty of care to persons not in privity. ${ }^{51}$ This was first accomplished by recognizing an exception to the rule of non-liability where there was a dangerous instrumentahity known to involve risk of personal injury to a third person..$^{52}$ This exception was extended so that knowledge of the risk on the part of the builder was no longer a prerequisite to recovery when the instrument was shown to be "imminently dangerous if negligently constructed." The exception was then enlarged to encompass property damage as well as personal injury, and it became no longer necessary to show that the structure was imminently dangerous. ${ }^{54}$ Recently, liability without privity has been said to be "a matter of policy to be determined by the balancing of several factors." $" 55$

The apparent generosity of the courts in finding a causal connection

49182 Cal. App. 2d 339, 6 Cal. Rptr. 469 (1960).

50159 Cal. App. 2d 322, 323 P.2d 792 (1958).

51 See notes 35-38 supra and accompanying text. See also Note, 32 So. CAL. L. REv. 203 (1959); Note, 22 So. Cax. L. Rev. 505 (1949).

62 See Johnson v. Long, 56 Cal. App. 2d 834, 123 P.2d 409 (1943).

53 E.g., Dow v. Holly Mfg. Co., 49 Cal. 2d 720, 321 P.2d 736 (1958); Hale v. Depaoh, 33 Cal. 2d 228, 201 P.2d 5 (1948); Tomchik v. Julian, 171 Cal. App. 2d 138, 340 P.2d 72 (1959); Freeman v. Mazzera, 150 Cal. App. 2d 61, 309 P.2d 510 (1957); Hogan v. Miller, 153 Cal. App. 2d 107, 314 P.2d 340 (1957).

54 See Sabella v. Wisler, 59 Cal. 2d 21, 377 P.2d 889, 27 Cal. Rptr. 689 (1963); Stewart v. Cox, 55 Cal. 2d 857, 362 P.2d 345, 13 Cal. Rptr. 521 (1961). See also 4 Santa Ciara LAWYER 141 (1963).

55 See note 36 supra and accompanying text. 
between misrepresentation and injury, finding that misrepresentations substantially induced a purchaser's course of action, suggesting the possibility of hability for negligent non-disclosure, finding negligent conduct, broadening negligence liability through the abrogation of the privity doctrine, extending liability to include damage to the original purchaser's vendee, requiring the vendor to disclose all he knows despite circumstances giving the purchaser notice that things are not as represented, and preventing the vendor from disclaiming liability-all these reflect recognition by the courts that there is great disparity in knowledge and bargaining position between vendor and purchaser in sales of mass produced housing. One may reasonably infer that the courts are attempting to adjust the two opposing positions or, in the alternative, to place the burden of loss on the one best able to carry it, the builder-vendor.

III

\section{WARRANTY}

Dean Prosser has stated that the "seller's warranty is a curious hybrid, born of the illicit intercourse of tort and contract, unique in the law." A successful suit for breach of warranty does not require proof of the seller's neghigence, fraud, or knowledge of the defect. ${ }^{57}$ The first product warranties were based on express representations made by the seller about the quality of his goods. ${ }^{58}$ During the nineteenth century, business practices developed to the point where reputable dealers stood by their products. This, together with an accompanying shift in judicial evaluation of the seller's responsibilities engendered the development of warranties of quality implied by operation of law as an intrinsic part of the sales transaction. ${ }^{59}$ The Uniform Sales Act reduced these warranties to two: a warranty of fitness for intended use, and one of merchantability. ${ }^{00}$ These warranties have been expanded by the courts to include many transactions not previously considered to be within the purview of the statute. ${ }^{11}$ Neither the Uniform Sales Act nor the Uniform Commercial

56 Prosser § 95, at 651.

57 Id. at 652 .

58 Id. at 653 .

${ }^{59}$ Id. at 651. See also Llewellyn, On Warranty of Quality and Society, 36 Corung. L. REv. 699, 717-22 (1936).

60 Untform Sales Act § 15 (Cax. Civ. Code § 1735) now Untrorar Comarercial Code $\S \S 2-314,2-315$ (CAL. CoMar. CoDE $\S \S 2314-15$ ).

61 See, e.g., Peterson v. Lamb Rubber Co., 54 Cal. 2d 339, 353 P.2d 575, 5 Cal. Rptr. 863 (1960) (defective grinding wheel); McNeal v. Greenberg, 40 Cal. 2d 740, 255 P.2d 810 (1953) (lease of equipment); Klein v. Duchess Sandwich Co. Ltd., 14 Cal. 2d 272, 93 P.2d 799 (1939) (sale of food); Valles v. Canada Dry Ginger Ale, Inc., 190 Cal. App. 2d 35, 11 Cal. Rptr. 823 (1963) (bottle containing soft drink); Gottsdanker v. Cutter Laboratories, 182 Cal. App. 2d 602, 6 Cal. Rptr. 320 (1960) (use of drugs on human beings); Drumar 
Code regulates real property matters, and the rule still persists in the majority of states that there is no implied warranty of quality or condition in the sale of real property. ${ }^{62}$

There has been a movement by the courts of some jurisdictions to find an implied warranty in the sale of new homes by a builder-vendor. ${ }^{63}$ In most cases a distinction is made between a liouse purcliased after completion and one purchased during construction, the latter carrying the implied warranty. The courts reason that once the house is complete the buyer can inspect for defects, but while it is still in the process of construction he cannot. ${ }^{64}$ This distinction has been criticized on several grounds. ${ }^{65}$ First, althougli a purchaser can inspect a completed house to a certain extent, most prospective home buyers lack the ability to make an adequate inspection and the funds to hire someone who can. ${ }^{66}$ Second, even if the purchaser has the requisite expertise or funds to hire an inspector, it would be better to inspect the louse during construction when the defects would be observable rather than after completion when many of the potential trouble spots are hidden. ${ }^{67}$ Third, when a person

Mfg. Co. v. Morris Ravine Mfg. Co., 33 Cal. App. 2d 492, 92 P.2d 424 (1939) (sale of second hand goods).

627 WIIIISTON, CONTRACIS $\$ 926$ (3d ed. 1963). However, the author of this treatise recommends that an implied warranty be found in the builder-vendor situation. $I d$. $\S 926 \mathrm{~A}$ at 818.

${ }^{63}$ See, e.g., F. \& S. Const. Co. v. Berube, 322 F.2d 782 (10th Cir. 1963); Glisan v. Smolenske, 387 P.2d 260 (Colo. 1963); Weck v. A. M. Sunrise Const. Co., 36 Ill. App. 2d 383, 184 N.E.2d 728 (1962); Vanderschrier v. Aaron, 103 Ohio App. 340, 140 N.E.2d 819 (1957) ; Jones v. Gatewood, 381 P.2d 158 (Okla. 1963) ; Loma Vista Dev. Co. v. Johnson, 177 S.W.2d 225 (Tex. Civ. App. 1943), rev'd on other grounds, 142 Tex. 686, 180 S.W.2d 922 (1944); Hoye v. Century Bldrs. Inc., 52 Wash. 2d 830, 329 P.2d 474 (1958); Jennings v. Tavener, [1955] 2 All E.R. 769; Perry v. Sharon Dev. Co., [1937] 4 All E.R. 390; Miller v. Cannon Hill Estates, [1931] 2 K.B. 113 (dictum); cf. White v. Mitchell, 123 Wash. 630, 213 Pac. 10 (1923); Lynch v. Thorne, [1956] 1 All E.R. 744. But cf. Coutrakon v. Adams, 39 Ill. App. 2d 290, 188 N.E.2d 780 (1963); Rappich v. Altermapp, 106 Ohio App. 282, 151 N.E.2d 253 (1957). See also Keating, The Fitness of Housing, 106 L.J. 743 (1956); 19 MODERN L. REv. 544 (1956); Note, 42 N.C.L. REv. 946 (1964).

64 This distinction originated with the English case of Miller v. Cannon Hill Estates Ltd., [1931] 2 K.B. 113, where the court rcasoned that a person who buys a house which is not yet completed has no opportunity to inspect the completed structure for defects while one who buys a finished house can. The court also argued that there was no guarantee that a person buying a completed house was intending to hve in it, and even if he was, he could have an express warranty of fitness for habitation included in the contract of sale. Conversely, the court argued, when a person buys a house while it is under construction he intends to live in it. In this situation the purchaser relies on the builder-vendor to construct a habitable house since he is unable to inspect the completed structure before he becomes bound on the contract. Consequently, the court reasoned, there should be an implied warranty both of quality and of fitness for habitation.

65 See generally Bearman; Dunhan, Vendor's Obligation as to Fiiness of Land for a Particular Purpose, 37 Mons. L. REv. (1953) [hereinafter cited as Dunham].

60 Bearman 545.

67 Ibid. 
buys a new house in a housing development he probably intends to live in it, particularly when he has mortgaged it, thus discounting the argument that he may be buying it for some purpose other than to live in. ${ }^{88}$ Finally, presence or absence of an implied warranty may turn on whether he buys the house one day before or one day after completion. The builder-vendor will build his houses in the same way in either instance; there is no reliance on his part requiring protection in one case and not the other. ${ }^{69}$ Consequently, there is no reason why one purchaser should receive the warranty and the other should not. In fact, in a recent case the Colorado Supreme Court has abandoned the distinction and the New Jersey Supreme Court has taken nearly the same position. In the Colorado case of Carpenter $v$. Donohue, ${ }^{70}$ the court held the defendant liable for a breach of warranty on a completed house when the plaster on the wall cracked shortly after the sale, declaring that any distinction between a finished and an unfinished house was "a distinction without reasonable basis ... ."11 In the New Jersey case, Schipper v. Levitt \& Sons Inc., ${ }^{72}$ the builder-vendor was held hable for breach of warranty as well as negligence for a defect in the design of the hot water system which caused personal injury to one of the plaintiffs; the court considered it unimportant that the house had not been completed before the sale.

One writer, arguing for expansion of warranty liability, has suggested some factors to be weighed in determining the utility of using it in a new area. ${ }^{73}$ The important ones are: first, who can best prevent or bear the loss; second, who can best distribute the risk; third, how large is the mdustry; and finally, is low cost insurance available. These considerations, when applied to the sale of real property by a builder-vendor, indicate that the extension of warranty liability to the sale of development homes is proper. The ordinary purchaser of a tract home, because of limited finances, is normally not in a position to bear a substantial loss without great hardship. Nor is he in a position to prevent the loss, because he lacks control over the construction of the house and lacks ability to perform a thorough inspection. Moreover, he is ordinarily in no position to distribute the loss because there is apparently no low cost

${ }^{68}$ Bearman 545; Dunham 119. Mortgages are used extensively as a means of purchasing property in California. One survey has shown that $83 \%$ of 3,699 title reports examined involved one or more encumbrances on the property being purchased. Griffith, Community Property in Joint Tenancy Form, 14 StaN. L. REv. 87 n.5 (1961)..

09 Bearman 546; Dunham 121.

70388 P.2d 399 (Colo. 1964).

71 Id. at 402.

7244 N.J. 70, 207 A.2d 314 (1965).

73 Farnsworth, Implied Warranties of Quality in Non-Sales Cases, 57 CoLum. L. REv. $653,670-74$ (1957). 
insurance available to a home purchaser to cover situations where neither party is at fault. ${ }^{74}$ On the other hand, the builder-vendor can prevent the loss by proper inspection and by choice of rehable sources of supply. Since it is usually cheaper to prevent the loss than to pay for it, placing the burden on the builder will encourage prevention of structural defects. ${ }^{75}$ Furthermore, a developer is more likely to have sufficient assets to bear the loss-he can either include the cost of insurance, or the amount of the loss if he prefers to bear the risk himself, in the price of the houses, and thus distribute the risk proportionally to all who purchase homes.

The situation in the sale of chattels when the courts expanded warranty hability was similar to the one that exists in the real property field today. In the words of Chief Justice Traynor:

As handicrafts have been replaced by mass production with its great markets . . . , the close relationship between the producer and consumer of a product has been altered. Manufacturing processes . . . are ordinarily either inaccessible to or beyond the ken of the general public. The consumer no longer has the means or skill enough to investigate for himself the soundness of a product, ... and his erstwhile vigilance has been lulled by the steady efforts of manufacturers to build up confidence by advertising and marketing devices ... . ${ }^{76}$

Several decisions of the California courts which have widened the coverage of cliattel sale warranty found sufficient justification in the inability of the buyer to protect himself by an adequate inspection. ${ }^{77}$ Since the inability of the buyer to protect himself as a result of the changed conditions of the inarketplace prompted the extension of warranty in the chattel sales field, ${ }^{78}$ it follows that a similar situation in real property sales should produce a like result. ${ }^{79}$

74 Letter From Oscar E. Larson, salesman, Wight Realty Co., Sacramento, Calif., to L. Donald Boden, August 26, 1965, on file in the office of the California Law Review.

75 There is evidence that many defects and thus much damage has been eliminated in industries that have been subjected to strict hability, which indicates that this consideration is vahid. See Llewellyn, On Warranty of Quality and Society: II, 37 CoLUM. L. REv. 34I, 407-08 (1937).

76 Escola v. Coca-Cola Bottling Co., 24 Cal. 2d 453, 467, 150 P.2d 436, 443 (1944) (concurring opinion).

77 See cases cited note 61 supra.

78 Llewellyn, supra note 59.

79 "There are no neaningful distinctions between ... mass production of hones and the mass production . . . and sale of automobiles and ... the pertinent overriding policy considerations are the same." Schipper v. Levitt \& Sons, 207 A.2d 314, 325 (N.J. 1965). In effect California has held that an implied warranty exists in the sale of automobiles when personal injury is involved, calling it strict hability in tort. Vandermark v. Ford Motor Co., 61 Cal. 2d 256, 391 P.2d 168, 37 Cal. Rptr. 896 (1964); Lascher, Strict Liability in Tort for Defective Products: The Road To and Past Vandermark, 38 So. CaI. L. Rev. 30 (1965) ; cf. Seely v. White Motor Co., 63 A.C. 1, 45 Cal. Rptr. 17 (1965). Simce New 
The courts in California now grant relief to a person who has contracted directly with a builder to have an improvement constructed on real property when the construction is defective and causes damage. No showing of fraud, negligence, or knowledge on the part of the builder is required..$^{80}$ Recovery is based on an implied warranty that the labor and inaterials are fit for their intended use. ${ }^{81}$ This produces the anomalous situation in which a person who contracts with a builder for the construction of a house has a warranty of fitness for intended use of both labor and material because of his reliance on the skill and judgment of the builder, whereas the purchaser of a tract home, who also must rely on the skill and judgment of the builder; has none. As both parties have relied on the contractor's skill to provide them with a house fit for habitation, ${ }^{82}$ and the contractor foresees this reliance in both instances, logic compels the conclusion that both should have the same warranty.

Nonetheless, such warranty liability has not been recognized in California. ${ }^{83}$ In the two cases in which the courts have expressly denied the existence of warranty, the damage was caused by a defect in the soil. The holdings were limited to the condition of the soil ${ }^{84}$ perhaps implying that a different result might be forthcoming were the damage the product of a defect in a building. Both decisions relied on California Civil Code section $1113^{85}$ which provides that no warranties are implied by the use of the word "grant" in a deed except that the grantee has not

Jersey recognizes an implied warranty in the sale of automobiles and in Schipper the court went on to find an implied warranty in the sale of housing, California slould reach the same result.

80 See Mack v. Hugh W. Comstock Associates Inc., 225 Cal. App. 2d 583, 37 Cal. Rptr. 466 (1964). In Mack the plaintiff recovered from the general contractor for breach of warranty, express and implied, when the radiant heating system was found to be defective. It was the subcontractor who breached the warranty originally. Cf. Aced v. Hobs-Sesack Plumbing Co., 55 Cal. 2d 573, 360 P.2d 897, 12 Cal. Rptr. 257 (1961) (defeetive radiant heating system); Kuitems v. Covell, 104 Cal. App. 2d 482, 231 P.2d 552 (1951) (defective roof).

81 See note 80 supra.

82 See Note, 18 MD. L. Rev. 332, 335 (1958).

83 Gustafson v. Dunman, Inc., 204 Cal. App. 2d 10, 22 Cal. Rptr. 161 (1962) ; Liberty Bldg. Co. v. Royal Indem. Co., 177 Cal. App. 2d 583, 2 Cal. Rptr. 329 (1960).

84 Gustafson v. Dunman, Inc., supra note 83, at 13, 22 Cal. Rptr. at 163; Liberty Bldg. v. Royal Inden. Co., supra note 83 , at 589, 2 Cal. Rptr. at 333.

85 "From the use of the word 'grant' in any conveyance by which an estate of inheritance or fee simple is to be passed, the following covenants, and none other, on the part of the grantor for himself and his heirs to the grantee, his heirs, and assigns, are implied, unless restrained by express terms contained in such conveyance:

1. That previous to the time of the execution of such conveyance, the grantor has not conveyed the same estate, or any right, title, or interest therein, to any person other than the grantee:

2. That such estate is at the time of the execution of such conveyance free from encumbrances done, made, or suffered by the grantor or any other person claiming under him." CAI. CIv. CoDE $\S 1113$. 
previously conveyed the property nor encumbered it. In Evans $v$. Faught, ${ }^{86}$ and Sisk v. Caswell, ${ }^{87}$ the courts have acknowledged the existence of two kinds of encumbrances; those which affect title, and those which affect the physical condition of the land. The latter are not encumbrances within the meaning of section $1113,{ }^{88}$ making the limitations contained therem inapplicable to warranties of quality and condition since such warranties pertain to the realty's physical condition. Resting the refusal to find an implied warranty of fitness on this code section, therefore, seems clearly erroneous. If the Califorma courts continue to refuse to extend warranty liability into real property sales they should base their refusal on something more convincing than a code section having no relevance to the problem. Since the same conditions that resulted in warranty hability in the chattel sales field exist in the sale of development hoines, the courts should follow the example of New Jersey ${ }^{89}$ and Colorado ${ }^{80}$ and extend implied warranties to such sales.

\section{IV}

\section{LIABILITY OF A IENDER}

A lender's position in the construction industry is unique, for it is customary for the same lender to loan money to both the developer and the purchaser. The amount loaned to a developer is based upon the esti-

80231 A.C.A. 772, 42 Cal. Rptr. 133 (1965). In Evans plaintiff-buyer sued defendant seller for breach of the implied convenant against encumbrances. Plaintiff had purchased a lease held by the county on a portion of the property he had acquired from defendant on which the county had erected a powder magazine. Although plaintiff knew of the lease and the powder magazine at the time of sale, he claimed both encumbrances breached the covenant. The court beld for plaintiff, saying that the unrecorded lease was an encumbrance within the meaning of California Civil Code $\$ 1113$, but that the powder magazine was not. The court said an encumbrance that was a pernuanent, open, and notorious pliysical burden on the land was not within the meaning of $\S 1113$. When sucl a physical burden is present, the court noted, it is reasonable to presume, in absence of express agreement, that both parties act with reference to it and that fair value is demanded and given by vendor and vendee respectively. A title encumbrance, on the other liand, does come under $\$ 1113$. Such an encumbrance, the court stated, is temporary in nature and capable of removal. It consists of a third party's right or interest in the land which would impede its alienability and thus diminish its value. Since quality and condition of property concern the physical state of land, any covenant or warranty pertaining to quality would not be within the purview of $\S 1113$.

8714 Cal. App. 377, 112 Pac. 185 (1910). In Sisk, plaintiff had agreed to convey the land to defendant free of all encumbrances. However, the deed reserved to plaintiff the right to use an existing ditch on the land for irrigation purposes. Plaintiff thereafter sued to enjoin defendant's interference with the ditch. The court held for plaintiff, saying that title encumbrances, not physical encumbrances, were prohibited by a covenant against encumbrances.

88 Evans v. Faught, 231 A.C.A. 772, 42 Cal. Rptr. 133 (1965).

89 Schipper v. Levitt \& Son, Inc., 44 N.J. 70, 207 A.2d 314 (1965).

90 Carpenter v. Donolue, 388 P.2d 399 (Colo. 1964). See also Haskell, The Case for an Implied Warranty of Quality in Sales of Real Property, 53 Geo. L.J. 633 (1965). 
mated value of the homes as shown by the plans. In order to protect its investment, the lender inspects the houses as they progress toward completion to insure that the plans are being complied with and to determine when the progress payments to the builder are due. Should the lender therefore be held liable to the purcliaser for defects in the house which the lender's inspection should have uncovered? If so, on what basis: negligence, misrepresentation, or warranty?

DeZemplen v. Home Federal Savings \& Loan Ass' $n^{01}$ suggests that liability should exist when a negligent misrepresentation has been made directly by the lender to the purchaser. In DeZemplen the purchasers agreed to excliange their boat for an encumbered apartment building. The boat was given to a third party to be delivered to the defendant seller upon completion of the apartment according to the specifications of the construction loan made by defendant Home Federal. The boat was released after representations of proper completion by both the owner of the apartment property and the agent of Home Federal. The agent's statement was made without reasonable grounds for beheving it to be true. The court ruled that the plaintiff's complaint, alleging misrepresentation against Home Federal based upon this declaration, stated a cause of action although privity of contract between the buyer and the lender did not exist. The court applied the relevant policy considerations $\mathrm{s}^{92}$ in the following manner: Defendant Hoine Federal was attempting to help the owner sell his property to the plaintiffs, thus making the effect of its action on the plaintiffs direct; with Home Federal aware of the condition of the property, the injury to the plaintiffs was foreseeable; the damage to the plaintiffs, that is, the loss of the boat and the possession of the defective and encumbered apartment house, demonstrate that the injury resulted from the plaintiffs' reliance on the representations; finally, the court concluded, this kind of conduct should not be "encouraged and protected by immunity from civil liability as would be the case if the plaintiffs, who were the only persons suffering loss, were denied the riglit of action for the neghigent misrepresentation. ${ }^{\text {"93 }}$

Compare this with a case where money is loaned only to the developer, no representations as to value or proper construction are made to the purchaser, and the lender negligently performs its inspection. If the lender's negligence is to create liability to the purcliaser, the lender must owe him a duty of care. In at least one case a superior court sustained a demurrer to a purchaser's cause of action claiming the lender, a savings

01221 Cal. App. 2d 197, 34 Cal. Rptr. 334 (1963).

92 See note 36 supra and accompanying text.

93 DeZemplen v. Home Federal Sav. \& Loan Ass'n, 221 Cal. App. 2d 197, 206, 34 Cal. Rptr. 334, 340 (1963). 
and loan association, was liable for its negligent inspection. ${ }^{94}$ The court reasoned that the provisions in the loan contract providing for the lender's right to inspect the houses and approve the choice of builder were for the lender's own protection and any potential benefit to the plaintiff was a collateral consideration. ${ }^{95}$ The court did point out, however, that if the plaintiff could allege and prove the lender's identification with the project was so complete that it had become a sponsor, a duty of care might arise in his favor. ${ }^{96}$ In a similar case a non-suit was granted at the close of the plaintiff's case, the trial court stating that, in the absence of legislation or some substantial identification of the lender with the builder's promotional campaign, the lender did not owe a duty of care to prospective purchasers. ${ }^{97}$

Where a lender intentionally or negligently misrepresents the value or condition of a house to a purchaser, liability on the part of the lender will probably be found as it was in DeZemplen. Were the lender to misrepresent the value of the houses in order to induce prospective purchasers to make their financial arrangements with it, the purchasers could probably recover on the basis of fraud in the inducement to contract. Moreover, a lending institution might, in furtherance of its competitive purpose, identify itself with the builder's sales campaign to such an extent as to raise a duty of care in favor of prospective purchasers, without becoming a partner in the development. For example, were the lender to advertise that it had inspected the homes and found them to be of certain quality or value, the courts might find a duty of care even thougli no other financial connection existed between the lender and any buyer or the seller. ${ }^{98}$ Ultimately, since it is assumed that privity of contract is not present, whether lability would result would depend on the relevant policy considerations, most specifically, the intention of the lender to affect the conduct of the purchaser and the foreseeability of resultant harm.

Thus the lender may be held for neghigent misrepresentation and, in some cases, for negligent inspection. However it is doubtful that the courts

94 Fiore v. Conejo Valley Dev. Co., Civil No. 47395, Cal. Sup. Ct., Ventura County, Jnne $25,1963$.

$95 \mathrm{Id}$. at 10.

96 Ibid.

97 Letter From James J. Biggins, attorney for the plaintiff, to L. Donald Boden, December 28, 1964, on file in the office of the California Law Review.

$98 \mathrm{~A}$ lender who was a joint venturer would certainly have a duty of care in favor of the purchaser. The requirements for a joint venture are: (1) a community of interest in the enterprize, (2) sharing the profits and losses, (3) joint participation in the conduct of the business, and (4) agreement, either oral or by conduct. Lasry v. Lederman, $147 \mathrm{CaI}$. App. 480, 305 P.2d 663 (1957). How much less association would give rise to a duty of care to the purchaser on the part of the inspecting lender is open to speculation. 
will hold the lender strictly hable because, unlike hability for negligence and intentional fraud which would coerce the lender into correcting its conduct, greater care on the lender's part would not remedy carelessness on the part of the builder except by indirect pressure. It would be better to coerce the builder directly by imposing warranty liability on him. Although strict liability applied to the lender would provide the innocent purchaser with a presumably solvent alternative defendant should the builder be insolvent, the price might be too higlı because the increased costs would perliaps force lending institutions to seek other fields of investment.

\section{CONCLUSION}

Duties and habilities of the seller of chattels have undergone substantial alteration. The seller's hability lias been progressively broadened to include: first, tort liability for concealing what he knew or ought to know; second, liability for failure to deliver wliat lie contracted to deliver; and finally, hability for breach of implied warranty-forcing him to answer for what he places on the market. ${ }^{90}$

The development of a builder's liability for a defective house parallels that of chattel sales law. It has moved from caveat emptor through tort liability for negligence, misrepresentation and concealment, to express contractual hability. The next step is implied warranty, and there are indications that the California courts are moving in that direction. The courts seen to recognize the inequality in knowledge and bargaining position between buyer and seller in an era of tract development and mass production; this recognition is demonstrated by their generosity in finding misrepresentation or negligent conduct and by the demise of the privity doctrine. The same conditions that brought about implied warranty in the chattel sales field now exist in the sale of development homes. Other jurisdictions are beginning to recognize implied warranties in the sale of real property. Whether warranties will be implied in California remains to be seen, but the signs point in this direction and clianges in commercial practice furnish sufficient justification.

L. Donald Boden

99 Llewellyn, supra note 59 , at 713. 